UDK: 159.942.5-053.4-049.4 Professional paper

\title{
THE BEING THERE OF ADULTS FOR PRESCHOOLERS IN DISTRESS
}

\author{
Maja Hmelak \\ Faculty of Education \\ University of Maribor \\ Republic of Slovenia \\ maja.hmelak@um.si
}

\section{Tjaša Šoba}

"Oton Župančič» Kindergarten Slovenska Bistrica

Republic of Slovenia

soba.tjasa97@gmail.com 


\section{ABSTRACT}

Distress in a preschooler is often the result of accumulated fear and the lack of (re)cognition and overcoming of circumstances that lead to it. Therefore, the role of an adult who will teach the child to recognize, accept and cope with stressful situations is important. On the basis of relevant literature, the authors of the article have determined the emergence and incidence of distress in preschool children and the presence of adults (both teachers and parents) and their importance for the child's coping with distress from the theoretical point of view. Special attention has then been paid to the strategies for coping with distress or fears that adults are supposed to master for themselves and the child, while at the same time the child should be taught these self-help approaches in the process of education.

Keywords: adult, preschool child, help, distress, fear, strategies. 


\section{INTRODUCTION}

Children often perceive different life circumstances and situations as distress or fear: fear of darkness, loss of a parent, unknown situation, sleep and the like. They experience it both at home and in the kindergarten. In both environments, however, adults (especially parents or teachers) are the ones who help the child when experiencing fear, provide support and comfort, and together seek strategies for managing fear. However, when they do not detect the children's fears or help them on time, it can also lead to distress. Šmid (2015) clearly points out that we need to think about the possibility of distress when we notice a change in a child's behaviour. If we know the child well, we will perceive the change much faster than if we do not know the child. However, we should be aware that children also feel their parents' distress, which in turn can lead to the child experiencing it as well.

\section{PURPOSE}

The purpose of the article is to present the role and importance of the adult in the context of the preschool child's distress by reviewing the relevant literature and synthesizing this knowledge.

\section{METHODOLOGY}

The article is a theoretical discussion on distress and fears experienced by preschool children and the role of adults in this. In doing so, we wanted to define:

- the emergence and incidence of distress in preschool children,

- the presence of adults and their importance for the child's coping with distress,

- strategies for coping with distress and fears.

\section{THE EMERGENCE AND INCIDENCE OF DISTRESS IN PR ESCHOOLERS}

Distress is an emotional state in which children cannot see a way out or cannot help themselves. Children experience distress as fear, cannot explain it, and do often not know its true cause. It causes internal restlessness and tension, which often impedes children's play and work, burdens them and occupies them internally. In doing so, it not only impedes their physical activity but also hinders their emotions and thinking. This often makes them less successful, dissatisfied, 
and unhappy (Bregant and Bregant, 1966). Younger children in particular show their feelings primarily through behaviour. It is our task to teach children from the moment they enter kindergarten that they can show what they feel and verbalize it afterwards (Šmid, 2015). We, as adults, need to help the child recognize, understand and accept different emotions, including fear. At the same time, we must let them know that they can always entrust their thoughts and problems to the person close to them. In this way, we encourage children to recognize their own hardships as well as to learn how to cope and deal with them. However, it is important for us as adults to recognize and respond to child's distress as quickly as possible.

Today, stress is primarily a change, a demand or an internal tension which is provoked or caused by external conditions, but the effects can also be internal (Mielke 1997; Boben-Bardutzky 2000; Ribič Hederih 2003; Kneževič 1997). Slivar (2009) points out that the concept of stress today includes the whole personality, not only its biological part, but also the area of mentality, individual behaviour and social communications. »The most common source of stress in children are demands and burdens that are something that is not yet perceptible to them. These include, in particular, problems with friends, death of a loved person, relocation, changing kindergarten, dangerous gorge, separation of parents, loss of a pet, high expectations and many other factors " (Hmelak and Lepičnik Vodopivec, 2015, 88-89). As Žorž (1997) points out, any distress is caused by unmet needs and impaired balance. When a need is unmet, the internal balance is disrupted, causing tension, excitement and a sense of threat. And it is precisely the experience of this tension that we call distress or stress. Hmelak and Lepičnik Vodopivec (2015) emphasize that in the recognition of stress or distress in children, we often encounter a sensitivity to stress, which depends mainly on the child and his or her previous experience, as well as unexpected responses and signs that are unknown to us or we would not associate them with fear. As such, the authors cite behaviour disorders, avoidance of stressful events, regressive response (rocking), increased dependence on adults, and others.

The child's thoughts and inner experiences, emotions and fears cannot be directly observed, but perceived or observed through the child's (changed) behaviour. The signs of a child's distress appear differently. As described by Bregant and Bregant (1966), a distressed child is often a child in whom melancholy and depression are present and such a child is often not able to be (genuinely) happy. Most of the time they are sad, calm, anxious. In the physical area, however, distress is often manifested in sleep disorders, with loss of appetite, diarrhea, skin rashes, asthma, as well as headaches and flushing. Habit disturbances often include thumb sucking, nail biting, hair stroking, speech aversion and the like. According to 
the authors, these habits may cease for a short time or be completely lost under certain pressure, but emotional distress will continue unless we remove the causes. According to Miller (2000), distress in the child is often also caused by internal tension in the child as the result of inappropriate behaviour of adults or when they do not take into account their developmental needs. Children may often find temselves in distress if they are part of a conflict due to their aspiration which they have some experience with, but at the same time, know it is not desirable for their parents. They become afraid of punishmet or losing their affection. This is precisely why children from birth until the age of five are most at risk when coping with distress, because at that age the child acquires all the impressions through emotions, not through reasoning. The child's experiences are accompanied by strong emotional states. If we do not meet the child's needs or do not meet them properly, at the right time and in the right way, his or her wishes will bring discomfort and inconvenience, which will turn into distress over time.

\section{THE PRESENCE OF ADULTS AND THEIR ROLE IN THE CHILD'S DISTRESS}

Adults play an important role in the child's experience of distress. They accustom and teach the child to recognize, express and show emotions. It is also important that they establish an appropriate relationship with children who will clearly know what they are or are not allowed, at the same time trusting the adult and knowing that, in case of problems, they can turn to, will be understood and assisted by adults. Varjačič-Rajko (2007) states that the hardships and traumas experienced by children are also reflected in their behaviour. A behaviour arising from distress is often difficult to manage for teachers and parents. It is important to understand that children express their emotions, frustrations and fears in this way, which is especially evident in younger children, as they are more likely to express themselves through actions than words. It is also good to know that controlling behaviour is not bad, but it has a positive effect on all participants in a group and a particular situation. Children who expresses feelings with behaviour are not to be condemned in any way even if they disrupt our plans, act aggressively, etc. Children do not plan their behaviour as well as outbreaks of anger, but simply express their feelings. However, Miller (2000) points out that the child's behaviour is conditioned by several factors at the same time and speaks about the importance of knowing the basic factors in a certain developmental stage of the child, since they will help us to understand the behaviour of the child. One of the leading factors is definitely egocentrism. Younger children do not yet understand that other people 
have their emotions, which do not depend on their own. They are also convinced that all people share the same ideas and feelings. For this reason, a younger child is impatient when a peer refuses to lend him/her a toy immediately. When an event occurs or we are in a given situation that is unfamiliar to the child but difficult and unpleasant at the same time, we must provide the child with relevant, the most realistic possible, information, using words and explanations that the child understands. Often, role-playing games can be used to overcome distress through which children are brought closer to the situation, making it easier for children to understand and accept it. However, we need to be prepared for different responses from children and they depend on each individual.

Schmidt (2015) talks about the importance of teaching children defeat since they can get defeated. At the same time, he states that disputes and conflicts are in no way to be resolved instead of children, but we need to teach children that this is something normal, but solvable, as well as that distress does not go away by itself, but something needs to be done. Children often think that bad things only happen to them, which is, of course, not true. Therefore, it is good to reach for children's literature within which children can identify with the main characters and their difficulties. Through fairy tales, children also learn that disputes and conflicts happen every day and that each can be solved. Through stories appropriate for children, they solve or gradually overcome their fears, anxieties and various kinds of distress. The importance of picture books is discussed by Schuster-Brink (1994), who presents picture books as a good tool for all parents and for professionals who work with children as part of their work. Through them, children perceive fears a little differently, while they can find answers to their unresolved questions and thoughts. Throughout the story, children identify with the main character or issue in the story. Fairy tales also make it easier for them to understand and perceive certain things that were not clear to them before.

\section{STRATEGIES FOR MANAGING DISTRESS OR FEAR IN PRESCHOOL GHILDREN}

Children who experience distress or stress express it through aggression, anger, absentmindedness, crying, boredom, etc. Many times we blame poor parenting as a cause of child behaviour, which is not quite the case. Overstressed children are not interested in creative playing and they are much more difficult to teach, since both require a certain level of concentration and patience from them. In all this, it is important to start from the fact that the child is unburdened and relaxed by nature. We need to be aware of the importance of having children relax and grow 
into healthy and creative personalities who will later cope with the modern way and the fast pace of life. Relaxation also helps to develop creativity while boosting self-esteem. We need to enable children to learn about their own, inner world of silence and peace, which will help them process the problems from the outside world, a world from which they draw energy and power and will soon be able to conquer on their own. Thus, game and movement as an inner world in which children are alone with themselves can also be a factor of their relaxation (Hmelak and Lepičnik Vodopivec, 2015).

Miller (2000) first cites drama play as one of the many ways to release stress in a preschool child. Children's relationships with peers are formed through drama plays, in which they assume different roles and pretend to be someone else, and through games. This activity is even more important for children and their relaxation as children do not process distress by talking about an unpleasant event the way adults do. Children usually process events through role play. During times of distress, children feel helpless, but when they process distress, they usually feel stronger. Role play or drama plays offer children the opportunity to experience empathy and other social interactions. As part of the game, children can identify with another person and experience the event from a different perspective. Through this activity, children also learn how to solve problems, make compromises and find solutions in situations of conflict. Another activity also mentioned by this author (ibid.) is a game that takes place in a corner with cubes, through which children can create smaller worlds and lead all characters in the game. Through this game, children are given the power to help them release negative emotions of helplessness, they can tell their own stories and express thoughts. Moreover, through this game, children try to create various situations and problems that they find solutions to during the game, and at the same time, this game gives them more control over the game, since here one child can take on multiple roles at once. Schuster-Brink (1994), however, is primarily concerned with the technique of relaxation through creation. He says that children are also relaxed by art or creation. Relieving stress through creative arts such as drawing, painting, collage, dance expression, singing can be very effective for a preschooler.

Here we should also mention dolls, which bring a lot of fun and joy to the kindergarten, while being one of the best therapeutic aids in the kindergarten. Dolls have an incredible power in overcoming children's problems. Miller (2000) believes that through a doll we can talk about problems and hardships without exposing an individual child. Children will trust the doll, tell it about the concerns and problems they often conceal from adults becuse they are afraid to talk about their problems. Talking to a doll is the most appropriate method if 
children are experiencing crisis or distress. Gerard Kaduson (2006) also outlines various strategies not only for coping with children, but also for trauma and their resolution. He defines the therapeutic power of the game in four different ways:

- Reliving a stressful situation that a child is not able to put into words but relives it through play. This is most easily relived through a structured game through which children transfer their stressful situation to an imaginary character in the game, become dominant in the activity or take control, as well as gradually assimilate the trauma through repeated trauma.;

- The strategy of the so-called "master" through which the child also relives the trauma, but is exclusively intrinsically motivated to play; through such a game or strategy the game satisfies the children's need to master the environment in which they live;

- Catharze mode, through which the child releases all tensions. In such a game, children express intense emotions, anger, fear, sadness, as well as relive traumas that they cannot or are unable to verbally express. The reasons for the children's inability to express themselves may be the severity of trauma or the lack of external support.;

- The strategy of compensation in relation to the outside world: through this game or therapy, children have the power to compensate for their real weaknesses, losses. Exaggeration gives them a seeming power over a world they do not have in reality.

These methods allow the child to assimilate to the traumatic situation and to overcome fears with satisfaction.

Somewhat different strategies are used in the Montessori concept. This concept of stress release is not addressed through play, but through work. During her observation of children, Maria Montessori came to the conclusion that children achieved integration of the self through work rather than play. After the work, which they chose by themselves, they became calmer, more relaxed and satisfied, despite the fact that their work required a great deal of concentration (Montessori, 2009). Which strategies we will implement depends entirely on both the possibilities we are given, and the children. Each child is different which means that each is relaxed by different things. It is possible that an activity which we planned for relaxation causes additional excitement and tension in the child. For this reason, it is important to have a good knowledge of the child we want to help before introducing compliance strategies. However, we can also help ourselves with the curriculum to overcome distress and, consequently, relax a child. Within this document, we find many advice that may help us. As stated by Miller (2000), 
one of the ways to relieve distress and stress in the long run is to create a permanent routine. It gives children a sense of security. For this reason, it is even more important that the schedule of work both in kindergarten and at home includes constant, recurring events such as: arrival time, daily greetings, talk time, activities, meals, free play, rest, etc. It is important that we stick to these routines or standard work schedules to ensure a sense of security for children. Varjačič-Rajko (2007) further emphasizes the importance of group work, where the time that we plan for group work or socializing within the group is also important. It is sometimes good to stimulate it completely automatically, without planned thinking about its value. Group time is important as we develop a sense of belonging in the child, it can be a haven for children experiencing distress, because with the help of different tools, we highlight topics in which children recognize themselves, but are not placed in the forefront. So we are talking about a neutral area. Within the group, children find it easier to solve common problems and thus help each other.

\section{CONCLUSION}

After reviewing the relevant literature, we found that it is important to observe and listen to a preschooler and be especially alert to any fears or distress. Their source can also be our usual daily routines and events, while preschoolers may experience them as a form of stress, especially if it is something occurring for the first time. In addition, each child's fear or distress is expressed in different ways. In any case, there is a visible change or deviation from the child's normal activities, behaviours, emotions. Likewise, every child experiences distress differently or responds differently to changes and events. While one does not perceive distress, another may.

From the perspective of the adult, it is important that the child's fear or potential distress is recognized and approached in an appropriate, professional manner, the problem is dealt with and solved. In doing so, we must be especially careful not to take children's fears for granted and thus insignificant, as well as not to additionally intensify or increase them. In order to be able to do this properly, we need to be professionally qualified, which is why continuing professional development in this field is important. However, the use of appropriate professional literature can help us greatly.

When confronting the distress of preschool children, it is essential that we clarify their fears to them or explain them in an understandable way. We need to teach children to recognize and express their own emotions and feelings, and to talk about everything with our children. Children need to understand that we all 
have fears and that there is nothing wrong if we are scared, worried or sad. For a successful resolution of distress and fears, it is also important that children have at least one adult to whom they are attached and can fully trust. Child need to be able to turn to and trust a person who is important to them.

It is therefore essential for children's overall development that we, as adults, are aware of the fears, distress and traumas that may affect them. We need to be aware that fears occur throughout the age of our growing up and that children will repeatedly need our help. At the same time, it is therefore necessary for preschool children to simultaneously learn strategies for self-help in times of distress. 


\section{REFERENCES}

1. Boben-Bardutzky, D. (2000). Obvladovanje stresa v šoli. Katarina, 5(4): 30-33.

2. Bregant, L., Bregant, M. (1966). Otrok v stiski. Ljubljana: Cankarjeva založba.

3. Gerard Kaduson, H. (2006). Release Play Therapy for children with Posttraumatic Stress Disorder. Retreived from: https://www.guilford.com/excerpts/kaduson old.pdf (1.11.2018.)

4. Hmelak, M., Lepičnik Vodopivec, J. (2015). Izbrane teme predšolske pedagogike. Koper: Univerzitetna založba Annales.

5. Kneževič, R. (1997). Teoretični uvod v sindrom izgorevanja. Defektologica Slovenica, 5(3): 28-34.

6. Mielke, U. (1997). Če z otrokom ni lahko. Radovljica: Didakta.

7. Miller, K. (2000). Otrok v stiski. Ljubljana: Educy.

8. Montessori, M. (2009). Skrivnost otroštva. Ljubljana: Uršulinski zavod za vzgoji, izobraževanje, versko dejavnost in kulturo.

9. Ribič Hederih, B. (2003). Otrok se spopada s stresom. Otrok in družina, 24(1): 24-27.

10. Schuster-Brink, C. (1994). Otroška vprašanja ne poznajo tabujev. Ljubljana: Založba Kres.

11. Slivar, B. (2009). Raziskava o poklicnem stresu pri slovenskih vzgojiteliicah, učiteliicah in učitelijh. Retreived from: http://www2.sviz.si/media/RAZISKAVA\%20O\%20DELOVNEM\%20 STRESU\%20PRI\%20SLOVENSKIH\%20uciteljih\%20in\%20vzgojiteljicah.pdf (10.5.2014.)

12. Šmid, D. (2015). Kako pomagati otroku v stiski. Kamnik. Retreived from: http://www.vrteckamnik.si/images/SVETOVALNA SLUZBA/KAKO POMAGATI OTROKU V STISKI.pdf (15.9.2018.)

13. Varjačič-Rajko, B. (2007). Prvič v vrtec. Ljubljana: Otroci.

14. Žorž, B. (1997). Stiska je lahko tudi izziv. Nova Gorica: Educa. 


\section{NAZOČNOST ODRASLIH KOD \\ PREDŠKOLSKOGA DJETETA U NEVOLJI}

\section{SAŽETAK}

Osjećaj nevolje kod predškolskoga djeteta često je posljedica nagomilanoga straha i nesposobnosti (pre)poznavanja i prevladavanja okolnosti koje su do toga dovele. Zato je u takvim situacijama važna uloga odrasle osobe koja će dijete naučiti prepoznati, prihvatiti i prevladati stresne situacije. Autorice su u članku, na temelju relevantne literature, s teorijskoga aspekta definirale nastanak i pojavnost osjećaja nevolje kod predškolskoga djeteta te nazočnost odraslih (odgojitelja i roditelja) i njihov značaj za djetetovo suočavanje s nedaćama. Nadalje, posebnu su pozornost posvetile strategijama suočavanja s nevoljama, odnosno strahovima koje bi odrasli trebali usvojiti za sebe i za dijete, a ujedno bi u odgojnom procesu trebali i dijete podučiti tim pristupima za samopomoć.

Ključne riječi: odrasli, predškolsko dijete, pomoć, nevolja, strah, strategije. 